\title{
Impact of Digital Marketing on Student Decision-Making Process of Higher Education Institution: A Case of Indonesia
}

\author{
Andriani KUSUMAWATI \\ Department of Business Administration, Faculty of Administrative Science, \\ Universitas Brawijaya, Malang, Indonesia \\ andriani_kusuma@ub.ac.id
}

Received date: 25 February 2019; Accepted date: 27 April2019; Published date: 20 June 2019

Copyright @ 2019 . Andriani KUSUMAWATI. Distributed under Creative Commons CC-BY 4.0

\begin{abstract}
The number of higher education institution in Indonesia both public and private increased in the last decade. With this kind of competition, it is more important than ever that universities find new ways to stand out and effectively market themselves to prospective students. The importance of the digital media as commercial platform is generally recognized by now and universities increasingly adopt online marketing channels compared to traditional ones. A vital issue of this research paper is to discover the process by which students use digital media and more specifically what the media's role is in the decision making process of choosing a university. This knowledge on the use of digital marketing in Higher Education Institutions (HEIs) especially as part of university marketing strategies is very crucial in order to compete for qualified students. The aim of this paper is to explore the impact of higher education institutions digital marketing on student decision making process. A qualitative research approach was employed in this study through semi-structured interviews, observation and documentation as data collection methods. This research involves a large public university in Indonesia which is actively engaged in managing institutional digital marketing media particularly at the university department of marketing and public relations. Creswell's analysis model was conducted and carried out inductively and interpreted with sentences that are logical and easily understood. Findings show that university marketing management engages with digital media since it has now become a trend in all the businesses around the globe including HEIs. Mostly, students engage social media to seek information about university before choosing the right one. The collaborative and engaging nature of social media provides an opportunity to balance the educational control since communication platform is built on opinions and experiences of students and other stakeholders.
\end{abstract}

Keywords: Digital Marketing, Decision-making process, Student, Higher Education Institutions (HEIs), Indonesia.

Cite this Article as: Andriani KUSUMAWATI (2019)," Impact of Digital Marketing on Student Decision-Making Process of Higher Education Institution: A Case of Indonesia", Journal of e-Learning and Higher Education, Vol. 2019 (2019), Article ID 267057, DOI: 10.5171/2019.267057 


\section{Introduction}

The development of digital marketing in Indonesia continues to increase quite promising from time to time. Indonesia's digital landscape is rapidly growing with the country's more than 260 million populations along with the rapidly rising number of internet users, striking $40 \%$ of social media penetration rate, and developing infrastructure. Moreover, with the growing economy, the digital literacy, and the rising urban population, Indonesia has a potential to become a place of digital creativity (GetCRAFT, 2017).

A survey by GetCRAFT (2017) in the paper "Indonesia's Digital and Landscape Marketing Reports" explains that the proliferation of digital platforms and improved technology savviness are making consumers more discerning about how they spend their time online. With this, there is a real emerging mindset shift among marketers, as they start to think as a publisher to lure prospects to their own channels with compelling contents, among other strategies. Their survey also explains that the digital landscape will always be changing and will continue to do so. However, regardless the channel, customers will always stay as the focal point of all marketing strategies. Digital media offers a bright future for marketers because as technology improves, there will be more innovative, effective, and greater ways to serve the customers' needs.

According to Martin's (2015) research that digital marketing has taken the world changes and the higher education sector is no exception. Without enrolment growth, colleges and universities will not sustain. College and universities have the challenge of maintaining relevance among students who are increasingly more reliant on technology as a communication source. This research result is in accordance with Sherman (2014) in Best Practices Guide "Proving the Value of
Digital Marketing in Higher Education", she explains that higher education has been undergoing a transition for many years. Both internal and external challenges are faced by HEIs worldwide. This challenge requires higher education marketing to move from glossy brochures to social media and the web to capture prospective students' attention. Colleges and universities are becoming more selective about spending and more aggressive in recruiting prospective students. On the other hand, increasing competition and rising prices have forced students to become more selective in their school choice.

A salient research published by Lorange (2017) in KeyStoneAcademic.com also asserts that most of the universities and education institutions now report that they are using digital marketing in some capacity to engage with students and reach potential applicants, and increasingly, higher education providers are reporting high levels from their digital marketing campaigns. Khausik (2017) also identifies that approximately $49.74 \%$ of the internet web page views come from mobile devices. This is the reason why most educational institutes are now looking to target the mobile audience for their marketing campaigns. It is estimated that mobile subscriptions will hit 9.3 million by the end of 2019, and the major share of this population will be students between the ages of 18-25 years old. Also, more than two-thirds of these students say that they prefer to receive a mobile message for any updates or reminders, which makes mobile marketing crucial for the educational industry. To target this particular audience, educational institutes are now putting an effort to make their content interesting and in an easily accessible format, so that they do not miss out on any potential business.

Although marketing touches every department and has a significant impact on the institution's success or failure (Sherman, 2014), its aplication is not 
easy. This is evidenced by Martin's (2015) research who explains that higher education social media administrators have the ability to multitask carrying on conversations with multiple people at once, often across multiple platforms, and at times, using multiple devices. Social media administrators are problem solvers, pros at transparency, and express a desire and willingness to go the extra mile to help constituents because admins understand how one bad experience can translate into a negative comment that then may turn the tide of sentiment instantly, creating an uncomfortable situation for everyone. Higher education social media administrators are innovators. However, Martin further explains that higher education social media administrators are also understaffed, underfunded, and overwhelmed. Research stated that students often visit social media after first visiting an institution's website. That means an enormous amount of traffic passes through institutionally sponsored social media accounts each day, 24 hours a day, and 365 days a year.

In accordance with those challenges, the Indonesian Strategic Plan of Directorate of Higher Education which is implemented on the 2025 Higher Education Long Term Strategy (HELTS) mentions that Indonesia will regard itself as - Smart and Competitive Indonesia in 2025 (Anonim, 2002 in Syahid \& Tulung, 2016). In 2015, several HEIs in Indonesia are encouraged to be an autonomous Higher Education in terms of management. At this point, one of emerging agendas that coincides with the rise of HELTS is the need to become a World Class University (WCU) for Higher Education in Indonesia (Syahid \& Tulung, 2016). This program requires HEIs in Indonesia to compete to be the best educational institution. It is also commensurate with the Ministry of Research, Technology and Higher Education which is always reminiscent to all HEIs in Indonesia, both private and public to continue innovate. Consequently, HEIs in Indonesia can no longer compete only with the fellow HEIs within the country, but also prepare to compete around the world (kelembagaan.ristekdikti.go.id, 2018) to attract international students.

This strategy is also in accordance with the Law of The Republic of Indonesia number 12 (2012, pp.1) regarding Higher Education with the consideration that: "in order to increase the national competitiveness to face the globalization in whole sectors, higher education is required to develop science and technology and produce intellectuals, scientists and/or professionals who are cultured and creative, tolerant, democratic, possess strong character, and brave to defend the truth in the interest of the nation." For this purpose, technology existence becomes prominence, which evidences that the role of digital marketing is imperative and mandatory. The issues related to digital marketing in HEIs are indispensable since digital marketing is able to accomplish internalization as one of Indonesian HELTS agenda. Therefore, this paper focuses on the role of digital marketing for both marketers and students, and also examines the influence of university digital marketing on the students' choice of higher education institution.

\section{Digital Marketing and Higher Education Institution}

Digital marketing is often referred to as 'online marketing', 'internet marketing' or 'web marketing'. Digital marketing is an umbrella term for the marketing of products or services using digital technologies, mainly on the Internet, but it also includes mobile phones, display advertising, and any other digital medium (Sathya, 2017). At the same time, according to Stokes (2013) digital 
marketing helps to create consumer demand by using the power of the interconnected and interactive web or in other words by using the power of the Internet, and satisfies this demand in new and innovative ways. It enables the exchange of currency but, more than that, it enables the exchange of attention for value.

An article published by Williams (2017) in Forbes Community Voice explains that the modern marketer must be extremely agile. But while change spawns creativity, the goals of marketing remain constant. Organization hires a marketer to communicate the right message at various stages of the funnel, raise brand awareness and loyalty, drive traffic and customer engagement, and implement methods that lead to conversions and sales. Although Forbes gives key digital marketing trends to prepare for in 20172018 which are all changing the profession, the basis for long-term success is unchanged: Human marketers must be determined to adapt. Tiago and Verissimo (2014) maintain that human interactions have changed significantly due to engagement on social networks; the rapid growth of web platforms has facilitated behavioral changes related to activities, habitats and interactions. Consumer behavior changes require organizations to re-strategy their marketing activities in digital space. Together with these processes, organizations must also be aware of how consumers' attitudes, values, and belief impact their digital marketing campaigns (Al Kailani \& Kumar, 2011), this proves that the two areas; business intelligence (BI) and customer insight (CI) need to be brought together to support a company's interactive marketing (Stone \& Woodcock, 2013).

According to Stone and Woodcock (2013), applications or content for digital marketing can be designed to engage with the consumer at any time and in any place, with the purpose of informing, educating, entertaining or providing insights for the brand. It is not just limited to casual information seeking for entertainment or leisure but has become a significant platform for taking crucial career decisions. Due to the recent trends in technological advancements, marketing channels and consumer behaviors have seen a shift which has impacted the consumer decision making process when it comes to product purchases. Consumers' engagement with brands has changed, thus organizations need to adapt their marketing strategies to reach them.

Digital marketing in higher education is considered important particularly since HEIs were pressured by the intense global competition. According to Maringe (2006), higher education has been transformed from the dependency of funding by government to the competitive markets. The transformation of higher education from the dependency on government funding to the competitive market indicates that universities have to compete for students in the recruitment markets. Therefore, it is important for the universities to understand ways to attract students and how to market themselves (Kusumawati, 2013).

Furthermore, Choudaha and Chang (2012) warn that the environment of intense competition globally amongst universities and budget cuts pressure universities to become more strategic and to focus on international student recruitment. This situation makes international student recruitment a highly valuable component to the financial viability of many universities in the United States and other countries. But recruitment of international students comes at a cost which relates to university budgets. Therefore, apart from using the traditional forms of recruitment methods, universities need to look beyond and experiment other forms of recruitment including social media (Choudaha \& Chang, 2012). They advise that in-depth understanding of global 
student mobility trends and their decision-making process will help consolidate institutional recruitment efforts more effectively.

In article "Digital marketing trends for higher education in 2017", Joly (2016) asserts that higher education marketing leaders have to master the art of blending powerful and personalized customer experiences with the science of measuring and optimizing the impact of their initiatives. This proves that higher education managers or directors now have to work extra hard to get high quality graduates. In this case, no different from other industries, competition among universities to attract prospective students is also very dependent on the strength of each college brand, regardless of the quality of college management and graduate output. There are bonding relations that is; the quality factor is also very much determining the strength of the college brand, in addition to other elements that form the power of the brand. In such, digital marketing in higher education is an essential part of recruitment, retention and communication process either for stakeholder, government, or shareholder. Starting from enrolment to on-campus awareness, creating an effective digital strategy helps colleges and universities target the students that are right for their school, and reach others who may be part of their personal need but without knowing it. Digital marketing in higher education is also important in connecting with alumni who may be active boosters and supporters or could be re-engaged with specific strategies (Spilker, 2017). The digital media phenomenon has begun to influence both higher education and students' decision-making process. On the part of students looking for potential universities or colleges to attend, they use social media and other new online communication channels to obtain information and other related university information.

\section{Research Method}

In order to conduct the study, a case study approach including interviews combined with observations has been used. A case study often investigates a social phenomenon or a general perspective of a specific subject (Yin, 2009; Christensen et al., 2010). For this research, a large public university in Indonesia was selected as a case site. A case study research is used to study the contemporary phenomenon in its real-life context (Yin, 1994) and it can be used where the research and theory are at their early, formative stages (Benbasat et al., 1987). Since the study strived for a broader understanding and deeper knowledge of marketing within HEIs; interviews, and observations were used. Due to the interest of conducting a study within the field of marketing of HEIs and how such institutions attract and enroll students, the study was delimited towards a public university in Indonesia. This suited the study's purpose as recommendations from strengthening marketing approaches have been constructed towards how the public university could attract and enroll students.

The introduction described the conditions that are taking place in the industry of HEIs, in combination with problems that Indonesia is facing towards competition within this industry. This was an influencing factor for the chosen topic since the recommendations presented constructive outputs not only for this university, but also for further studies within HEIs and higher education in Southeast Asia. The higher education industry in Indonesia has recently received a lot of attention due to increased competition and enhanced establishment of HEIs (Kusumawati, 2013). Since this study area is not that elaborated (Hemsley-Brown \& Oplatka, 2006) it also influenced the choice of topic. 
Data was collected using semi-structured interviews with key stakeholders of university marketing and recruitment management officer. Each interview included questions about the background of the organization, as well as its marketing and recruitment management practice, the participants' roles, and their views about the role of digital marketing for promoting the institution as well as influencing student choice of university. Additional information was obtained from students' participant and secondary data including reports and internal and external documents. Observation of digital media used by the university was also employed in order to complement the interviews. The purpose of these observations was to carry out a withincase (Yin, 2009) analysis based on multiple forms of data from a respective university. This enabled a more in-depth analysis, in comparison to only using a data from the staff and student interviews.

\section{Findings and Discussion}

Brawijaya University was first established into a state university on January 5, 1963, following a Presidential Decree issued earlier in the same year. This date was later promulgated as UB's anniversary (specifically called Dies Natalies among Indonesian academic society members) with acronym of UNBRA and then UNIBRAW, before UB being inaugurated as the official acronym of Universitas Brawijaya in 2008. With approximately 60,000 students in various degrees ranging from the Diploma Program, Bachelor's Degree Program, Master's Degree Program, Doctoral Degree Program, and Medical Specialist Program, in 16 Faculties, UB is the 5th largest university in Indonesia according to Webometrics world university ranking on 2017. Based on 4ICU world university ranking, UB's position on 2018 is on the 4th rank in Indonesia, going upward from the previous year's rank of the 6th. On Southeast Asia level, UB is on the 17 th.
At present, UB's website has a comprehensive and professional design look. Information such as student's admission, selection of degree programs, faculty-related links, and student services are available. However, the website only provides basic information (typically in a roundabout manner) and lacks depth in the info it could provide for potential students. A comment left behind by some of the students particularly mentioned that, "The website is not quite informative" and that information "did not give me confidence applying to UB". There is no complete information of the necessary courses for each degree, or detail on what these courses require. Other information that might be considered important for prospective students such as housing accommodation and location assistance (maps) were not provided and difficult to find. In terms of social media, UB has done well for itself with Facebook, as from this writing with 34,864 followers, Twitter with 159,000 followers, and Instagram with more than 40,000 followers. Beside these three social media, YouTube, Flickr, and RSS were also utilised by UB. Furthermore, on these social media pages, they do not show too much activity from students; most activities are from the university itself with slight to no reposts or comments by the followers.

\section{Digital Marketing as Marketing Strategy}

Stone and Woodcock (2013) explain that most corporations must now "market in a digital world". Pride and Ferrel (2016) explain that digital marketing uses all digital media, including the internet and mobile and interactive channels to develop communication and exchanges with customers. In the other hand, Stoke (2013) explains that digital marketing helps to create consumer demand by using the power of internet and satisfies this demand in new and innovative ways. 
The argument of Stone and Woodcock (2013) as well as the theory of digital marketing from Pride and Ferrel (2016) and Stoke (2013) support the research result obtained from the interview. The Research result from the public university can be described as follows: 1) Digital marketing in the HEI environment is a marketing strategy that employs through websites, social media, and other electronic media where these channels are a fast and inexpensive means of promotion, and are efficient given the distance and time; 2) Digital marketing in university environment is very useful for both university management and student. For university, digital marketing plays as promotional and communication tools, while for students, digital marketing might influence their choice of university, since the media provides two way communications and interaction as source of information obtained very fast, clearly and communicatively; 3) Digital marketing in the university environment acts as a lifestyle that constantly changing society such as using social media. Consequently, it can be concluded that university marketing uses digital media as one of its marketing strategies that are much needed and becoming a compulsory. This case is because the demands to follow the patterns of society life always change together with the rapid development of technology.

The Interview from the public university shows digital marketing as one of the marketing strategies that have engagement, such as: 1) Creating student awareness for more recognition regarding the university's services; 2) Digital marketing has a high impact to reach a large number of students; 3) It's for a low cost and provides a good return on investment; 4) Have the ability to display a wider service range due to the digital capabilities, for example easiness of communication and collecting feedback quickly; 5) Enables the public universities to quickly adapt their marketing initiatives to keep up with the recent trends; 6) Enables the public universities to provide engaging content and have different marketing communication dynamics across the different channels. Therefore, this research result is supporting previous research conducted by Reddy (2016) which complemented Stokes's idea who asserts that digital marketing has provided a new source of information for consumers and a platform to be social. On the other hand, Stokes' (2013) idea claims that digital marketing strategy has the essential guide both of context, value exchange, objectives, tactics and evaluation. The entire guide has each roles and engagement impacts.

The participants; both public university management and student, reveal that digital marketing space is easier to provide support and access an information compared with traditional marketing. University aligned their information through the digital marketing and traditional marketing channels so that the student receives the similar information. University always improves the communication approach on digital marketing programs in order to be more effective into their overall marketing strategies.

\section{Student Response to Digital Marketing Channel}

Research conducted by Martin (2015) explains that in higher education, social media has the multitasking ability, carrying on conversation with multiple people at once, often across multiple platforms, and at times, using multiple devices. The participant from this public university in Indonesia who employs digital marketing channels explains that social media and email are multitasking and also provide the way of communication easier or efficient when they connect with their students. Most of the participants give the opinion that digital marketing only serve as additional 
information on student choice of university since the decision was initiated by them. This result confirms Martin's (2015) research, who found that digital marketing could be a problem solver.

Martin (2015) also explain that digital marketing pros at transparency, express a desire and a willingness to go extra mile to help college's admin to filter like negative or positive comment in digital platforms. In this case, it is directly related with the current research result which found that digital marketing has a widespread impact, all information that students need can be searched through websites or social media but it is also an obstacle if something bad happens such as negative comments about public university or hoax which will quickly spread. The unfavorable experience requires public university to be aware since it causes losses, and therefore, they have to clarify the negative comment into positive comment effectively.

HEIs should be absolutely certain that they are not missing valuable opportunities to connect with students. Students often post questions that go unnoticed or unanswered. Sometimes, student approached to ask several questions through university digital media, therefore, HEI's should response those queries by utilizing a department or division to handle those enquires timely. When student queries are not responded by university, they might turn to a competing institution with the same question. HEIs must be present, available, accessible, and responsive in order to connect with students in digital marketing such as social media.

\section{Digital Marketing Engagement Impacts on Student Decision Making Process}

Digital marketing on student decision making processes is something that should change the purpose of digital marketing in educational institutions which only made it previously as a trend to provide information either to stakeholders or shareholders of a process that does not become just to know, especially students. It aims at directing students to have knowledge, making decisions (new thoughts or views) and solving problems in HEI as a success of the use of HEI's digital marketing, it also builds a good relationship between HEIs and students since both parties understand each other.

Noel (2009) states that marketing is a satisfying consumers' needs profitably, if marketers understand their consumers' needs and satisfy these needs. This is evidenced by the results of the interviews obtained from the public university showing that the marketing teams from the university still did not fully understand the needs of prospective students or scholars, they only followed the development of technology without seeing the real strategies and tactics so that the outcomes obtained were not satisfactory. The result of the interview from students also explains that their university does not completely understand the real needs of the students who always wanted to get satisfactory service both from the point of view of web design, the information conveyed and other digital marketing, there are even some misconceptions by students about who manages digital platforms in their university. On the other hand, students also cannot deny that digital marketing helps them in making decisions, they emphasize that the information they got through digital marketing only serve as an additional source in the decision making process. This research finding which explores digital marketing engagement on student decision making processes is also related with Kotler and Armstrong's (2014) concept who reveal that consumers pass through all five stages with every purchase but in more routine purchases, consumers often skip or reverse some of these stages. This argument also meets the conditions faced by students or 
prospective students when choosing a university.

In relation to the above literature, all participants indicated that digital marketing does trigger the student's need. Identifying the need of tertiary education is the first critical step in the student decision making process, as student should have a motivation for going to further study which might bring out better future of their career path and their own prestige to achieve the highest level of education. Digital marketing plays an important role in influencing students in identifying a need for education and through the digital space, Public Universities can align their marketing strategies to target students.

The next stage is the illustration of digital marketing's engagement impact on student choice, which consists of information search and evaluation of alternatives in the student decision making process. According to Kotler and Armstrong (2014), an interested consumer may or may not search for more information. If the consumer's drive is strong and a satisfying product is near at hand, he or she is likely to buy it then. If not, the consumer may store the need in memory or undertake an information search related to their need. The student processes information in order to find the right choice of education institution. In this step, students are not using a simple and a single evaluation process in all their choice situations. However, students went through evaluating the choice alternatives depending on the individual or a specific choice situation. Instead of student choosing by their own reference, sometimes they choose according to their family's recommendation. On the fifth stage, this can be more explain from the student retention of university or required situations of students to keep updating the information from their university.

\section{Conclusions}

This case study provided a better understanding of digital marketing impact on student decision making process in Higher Education Institutions (HEIs) in Indonesian Public University. The results emphasis that university marketing management employs digital media since its now becomes a trend in all businesses around the globe including HEIs. Moreover, in this year, digital marketing has vast progressed from previous year and educational institutions also take part of this technology advance which is always connected with their student via internet. Digital marketing is very essential and becomes a mandatory for all HEIs including public university as it follows the habit of current generation which continuously changes along with the rapid development of technology. Such digital marketing provides a low cost communication, a good return on investment, and has an ability to reach a wider community as well as ability to display whole service range due to the digital capabilities. Either public university or students also mention that they are easier to distribute and obtain information through digital marketing media compared with traditional marketing. Various interactions and responses could be obtained through social media since it has a multitasking function such as two ways communication, as well as being more effective and efficient with provided facilities such as comment columns, they also provide video and photo with little caption thus, they are easier to be understood by their audience. 


\section{References}

1. Al Kailani, M. and Kumar, R. (2011), 'Investigating uncertainty avoidance and perceived risk for impacting internet buying: A study in three national cultures,' International Journal of Business and Management, 6 (5), 76-83. Retrieved from

https://www.researchgate.net/publicatio $\underline{\mathrm{n} / 266571018}$.

2. Choudaha, R. and Chang, L. (2012), Trends in International Student Mobility. Retrieved on 12 April 2013, from http://www.wes.org/ewenr/12feb/featu re.htm.

3. GetCraft.com. (2017), 'White Paper Final: Indonesia's Digital and Content Marketing Reports in 2017,' GetCraft.com. Retrieved from https://www.slideshare.net/digitalinasia Lindonesia-digital...

4. Hemsley-Brown, J. and I. Oplatka, (2006), Universities in a competitive global marketplace. International Journal of Public Sector Management, 19(4): p. 316338.

5. Joly, K. (2016), 'Digital marketing trends for higher education in 2017,' accessed on January $7^{\text {th }} 2018$ from https://www.universitybusiness.com/art icle/digital-marketing-trends-higher-ed$\underline{2017}$

6. Kotler, P. and Armstrong, G. (2014), Principles of Marketing Global Edition (15 th Ed). Harlow: Pearson Education.

7. Kusumawati, A. (2013), 'Students' Perception of Choice Criteria in the Selection of an Indonesian Public University', University of Wollongong Thesis Collection. Retrieved from http://ro.uow.edu.au/theses/3933/
8. Kaushik, S. (2017), 'Current Digital Marketing Stats and Trends in Education Industry," accessed on January 28 2018 from https://armworldwide.com/currentdigital-marketing-stats-and-trends-ineducation-industry/

9. Lorange, P. (2017), 'Higher Education Digital Marketing', accessed on January $28^{\text {th }} 2018$ from https://www.keystoneacademic.com/hig her-ed-marketing/Higher-EducationDigital-Marketing

10.Martin, C. M. (2015), 'Social Media Engagement and Collegiate Recruitment: An Examination of the Use of Social Networks in the College Recruitment and Student Choice Processes', Dissertations. Paper 93. Retrieved from http://digitalcommons.wku.edu/diss/93

11.Noel, H. (2009), Basic marketing 01: Consumer Behavior. Switzerland: AVA Publishing SA. Retrieved from https://eshraghtranslators.com/educatio n/storage/book/uqQ7IpTPfpmulRotD4ui cRv7FajN7uaI1Bbq1UX0.pdf

12.Nuffic. (2015), 'Indonesian Education System,' Netherlands: Nuffic. Retrieved from

https://www.nuffic.nl/en/publications/fi nd-a-publication/education-systemindonesia.pdf

13.Pride, W. M. and Ferrell, O. C. (2016), Marketing, 18 Ed. Boston, USA: Cengage Learning.

14.PwC. (2015), 'The 2018 digital university: Staying relevant in the digital age,' PwC. Retrieved from https://www.pwc.co.uk/assets/pdf/the2018-digital-university-staying-relevantin-the-digital-age.pdf

15.Reddy, G. (2016), 'Digital Marketing Impact on the Consumer Decision Makin Process in Nike's Customer Retail

Andriani KUSUMAWATI (2019), Journal of e-Learning and Higher Education,

DOI: $10.5171 / 2019.267057$ 
Operations in South Africa,' Gordon Institute of Business Science. Retrieved from

https://repository.up.ac.za/handle/2263 $\lcm{59756}$

16.Sathya, P. (2017), 'A Study on Digital Marketing and its Impact', International Journal of Science and Research (IJSR), Volume 6, Issues 2. Retrieved from https://www.ijsr.net/archive/v6i2/ART2 017664.pdf

17.Sherman, R. (2014), 'Proving the Value of Digital Marketing in Higher Education,' $\mathrm{OHO}$ Interactive. Retrieved from https://www.oho.com/blog/provingvalue-digital-marketing-best-practicesguide-now-available

18.Spilker, J. (2017), '14 Higher Ed Marketing Leaders Share Their Top Digital Strategy Tips,' accessed on January $28^{\text {th }}$ 2018 from https://www.workzone.com/blog/digital -marketing-higher-education/

19.Stokes, R. (2013), eMarketing: The Essential Guide to Digital Marketing (5 $5^{\text {th }}$ $E d)$. Quirk Education Pty (Ltd). ISBN: 9780-620-56515-8. Retrieved from https://www.pdfdrive.com/emarketingthe-essential-guide-to-digital-marketingd18829702.html
20.Stone, M. D. and Woodcock, N. D (2013), 'Social Intelligence in Customer Engagement,' Journal of Strategic Marketing. Retrieved from https://www.researchgate.net/publicatio n/263491456.

21.Syahid, A. and Tulung, J. M. (2016), 'Quality Assurance and Accreditation in Religious Higher Education: Indonesian Cases,' International Journal of Humanities and Social Science Invention, Volume 5 Issue 10, PP.52-67. Retrieved from www.ijhssi.org

22.Tiago, M. T. P. M. B and Verissimo, J. M. C. (2014), 'Digital marketing and social media: Why bother?,' Business Horizons. 703-708. Retrieved from https://www.researchgate.net/publicatio n/265380521 Digital Marketing and Soc ial Media Why Bother

23.Williams, A. (2017), 'Key Digital Marketing Trends To Prepare For In 20172018,' accessed on 27th 2017 from https://www.forbes.com/sites/forbesco mmunicationscouncil/2017/09/06/keydigital-marketing-trends-to-prepare-forin-2017-2018/\#10a6d4dc5d1b

24.Yin, R. K. (2011), Qualitative Research from Start to Finish, First Edition. New York: The Guilford Press. Retrieved from http://soh.iums.ac.ir/uploads/32 28277 16.pdf

Andriani KUSUMAWATI (2019), Journal of e-Learning and Higher Education, DOI: $10.5171 / 2019.267057$ 